\title{
EFFECT OF COMPOST, BIO AND NPK FERTILIZATION ON ESSENTIAL OIL PRODUCTION OF YARROW FLOWERING TOPS, ACHILLEA MILLEFOLIUM, L.
}

\author{
M.A.H. Abdou", M.K. Aly ${ }^{*}$, K.Z. Ahmed ${ }^{* *}$, E.A. Hassan ${ }^{* * *}$ and H.M. Kamel ${ }^{* * * *}$ \\ * Hort. Dept., Fac. Agric., Minia Univ., Egypt. \\ ** Genetic Dept., Fac. Agric., Minia Univ., Egypt. \\ *** Agricultural Researches Center, Egypt. \\ ***** Ministry of Agric., Egypt.
}

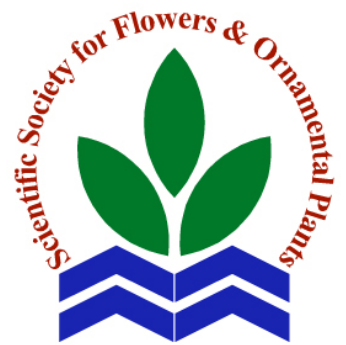

Scientific J. Flowers \& Ornamental Plants, 2(2):167-174 (2015).

Received:

22/7/2015

Revised by:

Prof. Dr. M.S. Hanafy, Cairo Univ.

Prof. Dr. Shadia K.

Ahmed, Hort. Res. Inst., ARC.

ABSTRACT: The effects of compost (5, 7.5 and 10 ton/fed), NPK (50, 75 and 100\%) and/or Effective micro-organisms/Minia Azotein fertilization on plant height, number and dry weight of flowering tops/plant and essential oil productivity ( $\%$ and yield/plant) were investigated during 2012/2013 and 2013/2014 at the experimental farm, Fac. of Agric., Minia Univ.

All treatments of compost significantly increased, plant height, number and dry weight of flowering tops/plant, as well as, essential oil percent and yield/plant. The high level of compost was more effective in this concern.

The used of mineral NPK (100\%) followed by $75 \%$ NPK + E.M. + M.A. treatments were the best results in increasing all previous characters.

Generally supplying yarrow plants with compost at the rate of 10 ton/fed and fertilizing plants with NPK $(100 \%)$ or reduce dose at $(75 \%$ NPK) plus E.M. + M.A. gave overall the highest values of previous traits.

Key words: Achillea millefolium, L., compost, biofertilization, E.M., NPK, flowering tops, essential oil.

\section{INTRODUCTION}

Achillea millefolium, L. (Fam. Asteraceae). Common name: yarrow. For medicinal purpose it has been used as administrated both internally and externally. It is valuable for treating wounds, stopping the flow of blood, treating colds, fevers, kidney diseases and menstrual pain (Duke, 1985, Bown, 1995, Chevallier, 1996 and Noerman, 1998).

Organic fertilizers are very important due to their beneficial effects on the soil, growth and increase the productivity, as well as, improving the quality of plant production (Aziz and Iman, 2004; Harb and Mahmoud, 2009 and Ferraz et al., 2014 on Achillea millefolium).
Chemical nutrients especially N, P and $\mathrm{K}$ are very important for plant growth and productivity (Giorgi et al., 2009 on Achillea collina; El-Mekawy, 2013 on Achillea santolina and Abd El-Latif, 2014 on lavender).

Biofertilizers increase crop growth and productivity through different mechanisms, i.e. biological nitrogen fixation as Effective micro-organisms and Minia Azotein, growth promoting or hormonal substances, increasing availability of soil nutrients (Hedge et al., 1999; El-Mekawy, 2013 on Achillea santolina and Panah and Vash, 2014 on Calendula officinalis).

Therefore, the purposes of this research were to investigate the effect of compost, 
mineral NPK and/or biofertilization treatments on growth and essential oil production of yarrow plants.

\section{MATERIALS AND METHODS}

This research was carried out at the experimental farm of Fac. of Agric., Minia Univ., during two consecutive seasons (2012/2013 and 2013/2014). Mechanical and chemical analysis of the soil were performed according to (Jackson, 1973) as shown in (Table, a).

Also, chemical characteristics of compost (Table, b), which obtained from the Egyptian Co. for Solid Waste Utilization, New Minia City.

Biofertilizers namely, Effective microorganisms (E.M., containing photosynthetic bacteria + lactic acid + yeasts) and Minia Azotein (M.A., containing N-fixing bacteria) were obtained from the Laboratory of
Biofertilizers, Dept. of Genetics, Fac. Agric., Minia Univ.).

The experiment was arranged in a randomized complete blocks design in a split-plot with three replicates. The main plots (A) included four treatments of compost (control, 5, 7.5 and 10 ton/fed). While seven treatments of mineral NPK and/or biofertilization occupied the sub-plots (B) $(100 \%$ NPK, $75 \%$ NPK + E.M., $50 \%$ NPK + E.M., 75\% NPK + M.A., 50\% NPK + M.A., $75 \%$ NPK + E.M. + M.A. and 50\% NPK + E.M. + M.A.).

The experimental unit (pot) was $3.0 \times$ $2.4 \mathrm{~m}$ and containing 5 rows, $60 \mathrm{~cm}$ apart. The seedlings were transplanted as individual plants in hills, $40 \mathrm{~cm}$ apart, therefore, each plot contained 30 plants.

Compost was added during preparing the soil to cultivation in both seasons.

Table a. Physical and chemical analysis of the experimental soil.

\begin{tabular}{|c|c|c|c|}
\hline Soil Character & Value & Soil Character & Value \\
\hline Sand \% & 28.30 & Available P \% & 15.12 \\
\hline Silt \% & 30.70 & Exch. $K^{+}$(mg/100 g soil) & 2.11 \\
\hline Clay $\%$ & 41.00 & $\operatorname{Exch} . \mathrm{Ca}^{++}(\mathrm{mg} / 100$ g soil $)$ & 31.74 \\
\hline Soil type & Clayey loam & Exch. $\mathrm{Na}^{+}$(mg/100 g soil) & 2.41 \\
\hline Organic matter $\%$ & 1.62 & \multirow{5}{*}{$\begin{array}{l}\text { DTPA } \\
\text { Ext. ppm }\end{array}$} & 8.54 \\
\hline $\mathrm{CaCO}_{3} \%$ & 2.09 & & 2.06 \\
\hline E.C. $(\mathrm{mmhos} / \mathrm{cm})$ & 1.04 & & 2.75 \\
\hline pH $(1: 2.5)$ & 7.83 & & 8.26 \\
\hline Total N \% & 0.08 & & \\
\hline
\end{tabular}

Table b. Physical and chemical properties of the used compost.

\begin{tabular}{lclc}
\hline Properties & Values & Properties & Values \\
\hline Dry weight of $\mathbf{1} \mathbf{~ m}^{\mathbf{3}}$ & $450 \mathrm{~kg}$ & $\mathbf{C} / \mathbf{N}$ ratio & $18.5-14.1$ \\
Fresh weight of $\mathbf{1} \mathbf{~ m}^{\mathbf{3}}$ & $650-700 \mathrm{~kg}$ & $\mathbf{N a C l} \%$ & $1.1-1.75$ \\
Moisture (\%) & $25-30$ & Total P \% & $0.5-0.75$ \\
pH (1:10) & $7.5-8$ & Total K \% & $0.8-1.0$ \\
E.C. (m mhose/cm) & $2-4$ & Fe ppm & $150-200$ \\
Total N \% & $1-1.4$ & Mn ppm & 25.56 \\
Org. matter \% & $32-34$ & $\mathbf{C u ~ p p m ~}$ & $75-150$ \\
Org. carbon \% & $18.5-19.7$ & $\mathbf{Z n ~ p p m}$ & $150-225$ \\
\hline
\end{tabular}


The recommended mineral NPK fertilization (full dose) 100\% NPK was 300 $\mathrm{kg} /$ fed ammonium nitrate $(33.5 \% \mathrm{~N}), 100$ $\mathrm{kg} /$ fed calcium superphosphate $\left(15.5 \% \mathrm{P}_{2} \mathrm{O}_{5}\right)$ and $50 \mathrm{~kg} /$ fed potassium sulphate $\left(48 \% \mathrm{~K}_{2} \mathrm{O}\right)$ according to El-Sayed (1986). While, $75 \%$ NPK were $225+75+37.5 \mathrm{~kg} /$ fed and $50 \%$ NPK were $150+50+25 \mathrm{~kg} / \mathrm{fed}$, respectively. All amounts of $\mathrm{P}$ fertilizer were added during the preparing the soil, while the amounts of mineral NK fertilizers were divided into three equal batches and added at one month interval, starting December $25^{\text {th }}$ in both seasons.

Fresh and active two biofertilizers, Effective micro-organisms (E.M.) and Minia Azotein (M.A.) applied either separately or in a mixture at three times at one month interval starting December $18^{\text {th }}$ for both seasons. Biofertilizers were added to the soil around each seedling $(50 \mathrm{ml} / \mathrm{seedling}, 1$ $\mathrm{ml}=10^{7}$ cells) and then seedlings were irrigated immediately. All other agricultural practices were carried out as usual in the region.

At the end of experiment, the following data were recorded: plant height $(\mathrm{cm})$, number of flowering tops per plant (flowering tops were collected 4 times every one month during the flowering season), dry weight of flowering tops/plant, essential oil percentage, oil yield (ml/plant).

Air-dried flower tops in each treatment carefully hand crushed to measure the percentage of essential oil according to (British Pharmacopoeia, 1963) by distilling $25 \mathrm{~g}$ of flowers for 4 hours in order to extract the essential oil.

The obtained data were tabulated and statistically analyzed according to MSTATC (1986) and L.S.D. test at $5 \%$ was followed to compare between the means.

\section{RESULTS AND DISCUSSION}

\section{1- Plant height (cm):}

Data obtained in (Table, 1) indicated that plant height was significantly increased as the compost treatments increased. So maximum plant height $(88.1$ and $89.8 \mathrm{~cm}$ for the first and second season, respectively) was achieved on 10 ton/fed compost. Several studies showed that compost could increase the growth of some medicinal plants such as yarrow (Aziz and Iman, 2004 and Harb and Mahmoud, 2009) and sage (Abdou et al., 2012).

Also, data in Table (1) indicated that, supplying yarrow plants with E.M. and/or M.A. combined with 75 or $50 \%$ NPK of the recommended dose resulted in a significant decrease on plant height in comparison with control $(100 \% \mathrm{NPK})$ in both seasons. The least reduction of the plant height was recorded with the treatment of $75 \%$ NPK + E.M. + M.A. The response of plant height to chemical NPK fertilization was reported by El-Mekawy (2013) on Achillea santolina and Jadhav et al. (2014) on Tagetes erecta. The interaction treatments was significant. The tallest plants produced by using 10 ton/fed compost in combination with $100 \%$ NPK.

\section{2- Flowering aspects:}

Data presented in Table (1) indicated that number and dry weight of flowering tops/plant of yarrow were gradually increased, in both seasons, parallel to the increase in compost level. The high level of compost (10 ton/fed) gave significantly higher values in both seasons than other treatments. Similar results were obtained by Harb and Mahmoud (2009) on yarrow and Ali (2013) on Calendula officinalis.

Concerning the treatments of mineral NPK and/or biofertilization data in Table (1) showed that fertilizing yarrow with NPK (100\%) followed by $75 \%$ NPK plus E.M. + M.A. produced the highest number and dry weight of flowering tops/plant in both seasons comparing with other five used treatments.

The role of NPK fertilizers in augmenting yield and weight of flowers was found by Harb and Mahmoud (2009) and ElMekawy (2013) on Achillea spp. and Khalif et al. (2014) and Maleki et al. (2014) on Calendula officinalis. Meanwhile, the 
Table 1. Effect of compost, bio and NPK fertilization on plant height (cm), number of flowering tops/plant and dry weight of flowering tops/plant of yarrow (Achillea millefolium, L.) plants during first and second seasons (2012/2013 and 2013/2014).

\begin{tabular}{|c|c|c|c|c|c|c|c|c|c|c|}
\hline \multirow{3}{*}{$\begin{array}{c}\text { Bio and NPK } \\
\text { fertilization treatments } \\
\text { (B) }\end{array}$} & \multicolumn{10}{|c|}{ Compost levels (ton/fed) (A) } \\
\hline & \multicolumn{5}{|c|}{$1^{\text {st }}$ season } & \multicolumn{5}{|c|}{$2^{\text {nd }}$ season } \\
\hline & 0.0 & 5.0 & 7.5 & 10.0 & $\begin{array}{c}\text { Mean } \\
(\mathrm{B}) \\
\end{array}$ & $\mathbf{0 . 0}$ & 5.0 & 7.5 & 10.0 & $\begin{array}{c}\text { Mean } \\
\text { (B) }\end{array}$ \\
\hline \multicolumn{11}{|c|}{ Plant height (cm) } \\
\hline $100 \%$ NPK & 86.9 & 89.1 & 97.5 & 99.0 & 93.2 & 88.7 & 90.9 & 99.0 & 101.0 & 95.0 \\
\hline 75\% NPK + E.M. & 70.2 & 80.4 & 94.1 & 94.8 & 84.9 & 71.6 & 82.0 & 96.0 & 96.7 & 86.6 \\
\hline 50\% NPK + E.M. & 63.0 & 75.2 & 73.8 & 81.9 & 73.5 & 64.3 & 76.8 & 75.2 & 83.5 & 75.0 \\
\hline 75\% NPK + M.A. & 68.7 & 79.2 & 86.4 & 92.3 & 81.6 & 70.0 & 80.8 & 88.1 & 94.2 & 83.3 \\
\hline 50\% NPK + M.A. & 58.1 & 60.6 & 55.2 & 65.3 & 59.9 & 59.3 & 61.7 & 56.3 & 66.7 & 61.0 \\
\hline 75\% NPK+E.M.+M.A. & 71.1 & 87.3 & 95.4 & 95.9 & 87.5 & 72.5 & 89.0 & 97.3 & 97.8 & 89.2 \\
\hline 50\% NPK+E.M.+M.A. & 65.1 & 78.6 & 78.3 & 87.3 & 77.3 & 66.3 & 80.1 & 79.8 & 89.0 & 78.8 \\
\hline Mean (A) & 69.0 & 78.7 & 82.96 & 88.1 & & 70.4 & 80.2 & 84.6 & 89.8 & \\
\hline L.S.D. at 5\% & \multicolumn{2}{|c|}{$A=2.97$} & $\mathrm{~B}=2.1$ & \multicolumn{2}{|c|}{$\mathrm{AB}=4.2$} & \multicolumn{2}{|c|}{$\mathrm{A}=3.28$} & $\mathrm{~B}=0.94$ & \multicolumn{2}{|c|}{$\mathrm{AB}=1.88$} \\
\hline \multicolumn{11}{|c|}{ Number of flowering tops/plant } \\
\hline $100 \%$ NPK & 45.32 & 48.77 & 50.29 & 54.40 & 49.70 & 47.68 & 49.91 & 52.54 & 54.86 & 51.26 \\
\hline 75\% NPK + E.M. & 41.19 & 43.23 & 45.47 & 47.46 & 44.34 & 41.40 & 44.01 & 46.32 & 47.85 & 44.90 \\
\hline 50\% NPK + E.M. & 34.67 & 35.91 & 37.66 & 39.68 & 37.00 & 33.10 & 35.60 & 37.52 & 40.08 & 36.58 \\
\hline 75\% NPK + M.A. & 39.46 & 40.40 & 42.82 & 45.00 & 41.93 & 38.22 & 39.92 & 42.23 & 44.42 & 41.21 \\
\hline 50\% NPK + M.A. & 29.72 & 31.32 & 33.86 & 35.79 & 32.67 & 28.71 & 32.24 & 34.11 & 37.28 & 33.09 \\
\hline 75\% NPK+E.M.+M.A. & 43.83 & 47.62 & 49.43 & 51.84 & 48.19 & 46.68 & 48.31 & 50.95 & 53.32 & 49.82 \\
\hline 50\% NPK+E.M.+M.A. & 37.78 & 38.88 & 39.91 & 42.06 & 39.66 & 36.32 & 37.56 & 39.81 & 41.16 & 38.71 \\
\hline Mean (A) & 38.85 & 40.87 & 42.78 & 45.17 & & 38.87 & 41.08 & 43.36 & 45.57 & \\
\hline L.S.D. at5 \% & \multicolumn{2}{|c|}{$\mathrm{A}=1.39$} & $B=1.60$ & \multicolumn{2}{|c|}{$\mathrm{AB}=3.20$} & \multicolumn{2}{|c|}{$\mathrm{A}=1.21$} & $\mathrm{~B}=1.51$ & \multicolumn{2}{|c|}{$\mathrm{AB}=3.02$} \\
\hline \multicolumn{11}{|c|}{ Dry weight of flowering tops /plant (g/plant) } \\
\hline $100 \%$ NPK & 54.75 & 58.92 & 60.76 & 65.70 & 60.03 & 57.60 & 60.29 & 63.48 & 66.27 & 61.92 \\
\hline 75\% NPK + E.M. & 49.86 & 52.33 & 55.05 & 57.46 & 53.68 & 50.12 & 53.28 & 56.08 & 57.93 & 54.35 \\
\hline 50\% NPK + E.M. & 42.25 & 43.76 & 45.90 & 48.36 & 45.07 & 40.33 & 43.39 & 45.73 & 48.85 & 44.58 \\
\hline 75\% NPK + M.A. & 47.88 & 49.02 & 51.96 & 54.61 & 50.88 & 46.38 & 48.46 & 51.25 & 53.90 & 50.00 \\
\hline 50\% NPK + M.A. & 36.30 & 38.25 & 41.35 & 43.71 & 39.90 & 35.06 & 39.37 & 41.68 & 45.54 & 40.42 \\
\hline 75\% NPK+E.M.+M.A. & 53.07 & 57.66 & 59.85 & 62.77 & 58.34 & 56.51 & 57.30 & 62.88 & 66.65 & 60.84 \\
\hline 50\% NPK+E.M.+M.A. & 45.95 & 47.03 & 48.77 & 51.14 & 48.22 & 49.29 & 45.07 & 47.75 & 49.37 & 47.87 \\
\hline Mean (A) & 47.15 & 49.57 & 51.94 & 54.82 & & 47.90 & 49.59 & 52.70 & 55.50 & \\
\hline L.S.D. at 5\% & \multicolumn{2}{|c|}{$\mathrm{A}=1.98$} & $B=1.70$ & \multicolumn{2}{|c|}{$\mathrm{AB}=3.40$} & \multicolumn{2}{|c|}{$A=1.68$} & $\mathrm{~B}=1.28$ & \multicolumn{2}{|c|}{$\mathrm{AB}=2.56$} \\
\hline
\end{tabular}

E.M.: Effective micro-organisms

M.A.: Minia Azotein (N-fixing bacteria) 
Table 2. Effect of compost, bio and NPK fertilization on oil percentage and oil yield/plant of yarrow (Achillea millefolium, L.) plants during first and second seasons (2012/2013 and 2013/2014).

\begin{tabular}{|c|c|c|c|c|c|c|c|c|c|c|}
\hline \multirow{3}{*}{$\begin{array}{c}\text { Bio and NPK } \\
\text { fertilization treatments } \\
\text { (B) } \\
\end{array}$} & \multicolumn{10}{|c|}{ Compost levels (ton/fed) (A) } \\
\hline & \multicolumn{5}{|c|}{$1^{\text {st }}$ season } & \multicolumn{4}{|c|}{$2^{\text {nd }}$ season } & \multirow[b]{2}{*}{$\begin{array}{c}\text { Mean } \\
\text { (B) }\end{array}$} \\
\hline & 0.0 & 5.0 & 7.5 & 10.0 & $\begin{array}{c}\text { Mean } \\
\text { (B) }\end{array}$ & 0.0 & 5.0 & 7.5 & 10.0 & \\
\hline \multicolumn{11}{|c|}{ Essential oil percentage } \\
\hline $100 \%$ NPK & 0.672 & 0.736 & 0.774 & 0.800 & 0.746 & 0.673 & 0.742 & 0.793 & 0.796 & 0.751 \\
\hline 75\% NPK + E.M. & 0.543 & 0.565 & 0.593 & 0.609 & 0.578 & 0.546 & 0.572 & 0.581 & 0.606 & 0.576 \\
\hline 50\% NPK + E.M. & 0.450 & 0.479 & 0.511 & 0.542 & 0.496 & 0.445 & 0.475 & 0.504 & 0.533 & 0.489 \\
\hline 75\% NPK + M.A. & 0.476 & 0.549 & 0.562 & 0.600 & 0.547 & 0.477 & 0.540 & 0.568 & 0.585 & 0.542 \\
\hline 50\% NPK + M.A. & 0.384 & 0.428 & 0.446 & 0.469 & 0.432 & 0.387 & 0.425 & 0.463 & 0.482 & 0.439 \\
\hline 75\% NPK+E.M.+M.A. & 0.697 & 0.719 & 0.748 & 0.756 & 0.730 & 0.713 & 0.731 & 0.746 & 0.755 & 0.736 \\
\hline 50\% NPK+E.M.+M.A. & 0.463 & 0.504 & 0.542 & 0.568 & 0.519 & 0.463 & 0.505 & 0.536 & 0.559 & 0.516 \\
\hline Mean (A) & 0.514 & 0.555 & 0.583 & 0.606 & & 0.514 & 0.555 & 0.583 & 0.601 & \\
\hline L.S.D & \multicolumn{2}{|c|}{$\mathrm{A}=0.022$} & $\mathrm{~B}=0.022$ & \multicolumn{2}{|c|}{$\mathrm{AB}=0.044$} & \multicolumn{2}{|c|}{$\mathrm{A}=0.016$} & $B=0.024$ & \multicolumn{2}{|c|}{$\mathrm{AB}=0.048$} \\
\hline \multicolumn{11}{|c|}{ Essential oil yield/plant (ml/plant) } \\
\hline $100 \%$ NPK & 0.37 & 0.43 & 0.47 & 0.53 & 0.45 & 0.39 & 0.45 & 0.50 & 0.53 & 0.47 \\
\hline 75\% NPK + E.M. & 0.27 & 0.30 & 0.33 & 0.35 & 0.31 & 0.27 & 0.30 & 0.33 & 0.35 & 0.31 \\
\hline 50\% NPK + E.M. & 0.19 & 0.21 & 0.23 & 0.26 & 0.22 & 0.18 & 0.21 & 0.23 & 0.26 & 0.22 \\
\hline 75\% NPK + M.A. & 0.23 & 0.27 & 0.29 & 0.33 & 0.28 & 0.22 & 0.26 & 0.29 & 0.32 & 0.27 \\
\hline 50\% NPK + M.A. & 0.14 & 0.16 & 0.18 & 0.20 & 0.17 & 0.14 & 0.17 & 0.19 & 0.22 & 0.18 \\
\hline 75\% NPK+E.M.+M.A. & 0.37 & 0.41 & 0.45 & 0.47 & 0.43 & 0.40 & 0.42 & 0.47 & 0.50 & 0.45 \\
\hline 50\% NPK+E.M.+M.A. & 0.21 & 0.24 & 0.26 & 0.29 & 0.25 & 0.23 & 0.23 & 0.26 & 0.28 & 0.25 \\
\hline Mean (A) & 0.24 & 0.28 & 0.30 & 0.33 & & 0.25 & 0.28 & 0.31 & 0.33 & \\
\hline L.S.D. at $5 \%$ & $\mathrm{~A}=0$. & & $\mathrm{B}=0.04$ & $\mathrm{AB}=0$ & & $\mathrm{~A}=0 . \mathrm{C}$ & & $\mathrm{B}=0.03$ & $\mathrm{AB}$ & 0.06 \\
\hline
\end{tabular}

E.M.: Effective micro-organisms

M.A.: Minia Azotein (N-fixing bacteria)

efficiency of biofertilizers was revealed by Abd El-Raaof (2009) on borage and Shivaprakash et al. (2011) on Tagetes erecta.

The interaction treatments was significant in both seasons and the highest values were obtained with the interaction treatments of compost $(10$ ton/fed $) \times 100 \%$ NPK followed by compost (10 ton/fed) $\times$ $75 \%$ NPK + E.M. + M.A.

\section{3- Essential oil production:}

Data presented in Table (2) indicated that all of the three tested treatments of compost (5, 7.5 and 10 ton/fed) gave significantly in the two seasons higher percentage and yield of essential oil/plant than that of the control. The high level of compost recorded the highest values.

Applying organic manure not only relieved material inhibition an autotoxic substance in the root exudates by cinnamic acid but also promoted growth, increased the content and composition of plant secondary metabolites (essential oils or alkaloids), (Zheljazkov, 2005).

Supplying plants with adequate quantities of NPK led to an increase in growth consequently, increasing the overall flower production which reflect on essential 
oil yield similar, Giorgi et al. (2009) on Achillea collina, El-Mekawy (2013) on Achillea santolina and Abd El-Latif (2014) on lavender plants.

Moreover, microbiological fertilizer has a positive effect in growing the plants to their development and metabolism and reported by Abd El-Raaof (2009) on borage and Saburi et al. (2014) on basil.

Also, data in Table (2) indicated that significant differences were obtained among the seven tested treatments in both seasons. The highest essential oil percentage and yield/plant was given by $100 \%$ NPK treatment or $75 \%$ NPK + E.M. + M.A. with no significant differences being obtained between them.

The interaction between compost and mineral NPK and/or biofertilization treatments was significant for essential oil \% and yield per plant in both seasons. The best overall results, among different interaction treatments were obtained due to compost at high level (10 ton/fed) in combination with $100 \%$ NPK or $75 \%$ NPK plus E.M. + M.A.

\section{REFERENCES}

Abd El-Latif, M.T.M. (2014). Physiological Studies on Lavandula officinalis Plants Ph.D. Thesis, Fac. Agric., Minia Univ.

Abd El-Raaof, R.M.E. (2009). Response of Borage Plants to Some Organic and Biofertilization Treatments. Ph.D. Thesis, Fac. Agric., Minia Univ., Egypt.

Abdou, M.A.H.; Abdalla, M.Y.; Helaly, A. and Mosaad, S. (2012). Physiological studies on sage plant. Minia J. of Agric. Res. \& Develop., 32(2):161-186.

Ali, F.A.F. (2013). Effect of Organic and Biofertilization Treatments on Pot African Marigold (Calendula officinalis, L.) Plants. M.Sc. Thesis, Fac. Agric., Minia Univ.

Aziz, E. and Iman, E. (2004). Comparative study on the effect of ammonium nitrate and ammonium sulphate through the application of poultry manure on the productivity of Achillea millefolium, L. plants. Arab Univ. J. Agric., Ain Shams Univ., Cairo, 12(1):371-389.

Bown, D. (1995). Encyclopedia of Herbs and Their Uses. Dorling Kindersley, London, ISBN 0-7513-020-31.

British Pharmacopoeia(1963). Determination of Volatile Oil Drugs. The Pharmaceutical Press, London.

Chevallier, A. (1996). The Encyclopedia of Medicinal Plants. Dorling Kindersley. London, ISBN 9-780751-303148.

Duke, J.A. (1985). Medicinal Plants of China. Reference Publications, Inc. ISBN: 0-917256-20-4.

El-Mekawy, M.A.M. (2013). Response of Achillea santolina, L. to fertilizers under different irrigation intervals. Asian Journal of Crop Science, 5(4):338-359.

El-Sayed, A.A. (1986). Effect of Nitrogen Fertilization and Some Growth Regulators on Yarrow Plants (Achillea millefolium, L.). M.Sc. Thesis, Fac. Agric., Minia Univ.

Ferraz, E.O.; Vilela, B.S.K.; Pinto, J.E.B.P.; Braga, A.F. and Costa, A.G. (2014). Organic systems in the growth and essential oil production of the yarrow. Revista Ciência Agronômica, 45(1):111119.

Giorgi, A.; Mingozzi, M.; Madeo, M.; Speranza, G. and Cocucci, M. (2009). Effect of nitrogen starvation on the phenolic metabolism and antioxidant properties of yarrow (Achillea collina, Becker ex Rchb.). Food Chemistry, 114:204-211.

Harb, E.M.Z. and Mahmoud, M.A. (2009). Enhancing of growth, essential oil yield and components of yarrow plant (Achillea millefolium) grown under save agriculture conditions using zeolite and compost. $4^{\text {th }}$ Conf. on Recent Technologies in Agriculture, 586 - 591.

Hedge, D.M.; Dwivedi, B.S. and Sudhakara, B.S.S. (1999). Biofertilizers for cereal 
production in India - A review. Indian $\mathrm{J}$. Agric. Res., 69(2):73-83.

Jackson, M.L. (1973). Soil Chemical Analysis Englewood Cliffs., New Prentice-Hall INC., New York.

Jadhav, P.B.; Alka, S.; Mangave, B.D.; Patil, N.B.; Patel, D.J.; Dekhane, S.S. and Kireeti, A. (2014). Effect of organic and inorganic fertilizers on growth and yield of African Marigold (Tagetes erecta, L.) Cv. Pusa Basanti Gainda. Annals of Biological Research, 5(9):10-14.

Khalif, E.; Pirdashtih, H.; Bahmanyar, M.A. and Ghsemkheilif, T. (2014). Effect of organic and chemical fertilizer on soil properties and nutrient concentration in pot marigold (Calendula officinalis, L.) Iranian J. of Medicinal and Aromatic plants, 30(3):476-485.

Maleki, A.; Feizolahi, A.; Naseri, R. and Heydari, M.M. (2014). Effect of different sources on vegetative characteristic of Pot marigold (Calendula officinalis) Inter. J. of Biosciences, 5(1):242-249.

MSTAT-C (1986). A Microcomputer Program for the Design, Management and Analysis of Agronomic Research Experiments (Version 4.0), Michigan State Univ., U.S.
Noerman, D. (1998). Native American Ethnobotany. Timber Press, Oregon. ISBN: 0-88192-453-9.

Panah, D.D. and Vash, F.F. (2014). The effect of biological and chemical fertilizers on yield of Calendula offinalis in greenhouse conditions. J. Novel Applied Sci., 3(12):1435-1438.

Saburi, M.; Hadi, M.R.H.S. and Darzi, M.T. (2014). Effects of amino acids and nitrogen fixing bacteria on quantitative yield and essential oil content of basil (Ocimum basilicum). Agric. Sci. Dev., 3(8):265-268.

Shivaprakash, B.N.; Hugar, A.H.; Kurubar, A.R. Vasudevan, S.N. and Husain, S.A. (2011). Studies on impact of biofertilizers and $\mathrm{GA}_{3}$ on growth and flower yield of marigold (Tagetes erecta, L.) cv. Orange Double, The Asian Journal of Hort., 6(2):406-411.

Zheljazkov, V.D. (2005). Assessment of wool waste as soil amendment and nutrient source. J. of Environmental Quality, 36(6):2310-2317.

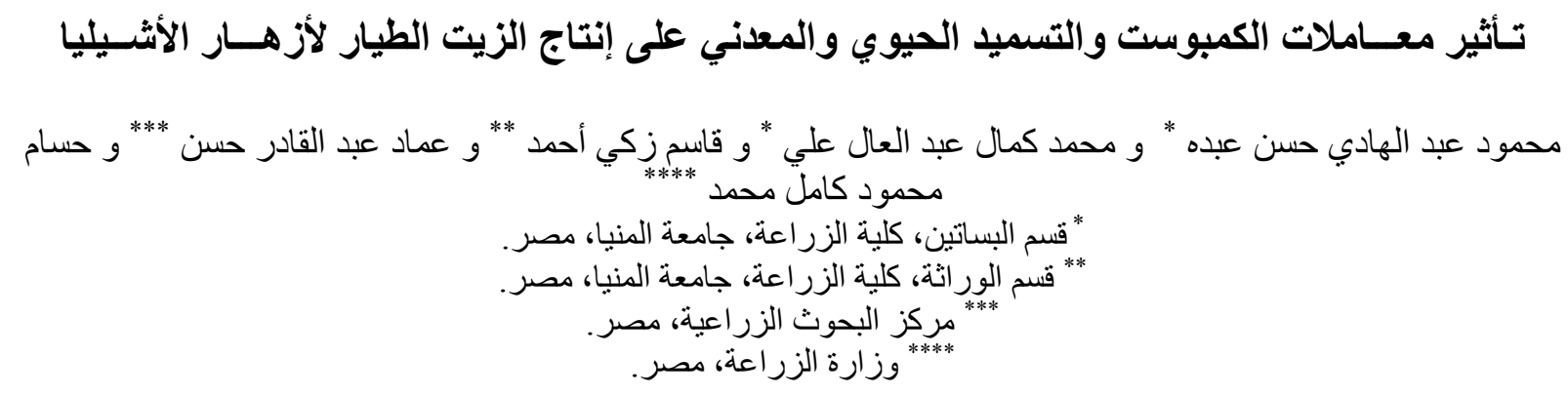

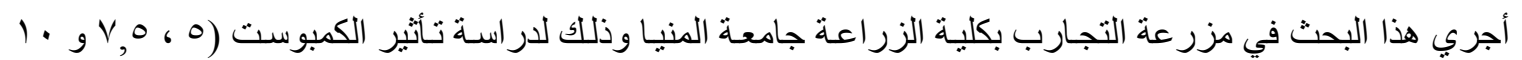

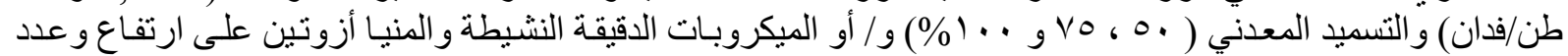

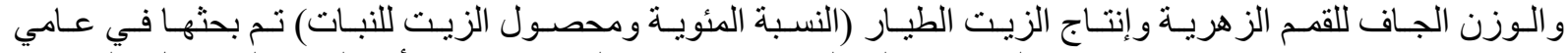

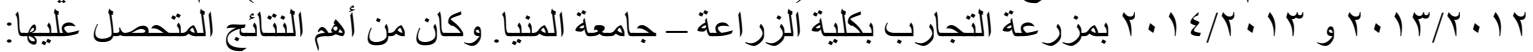

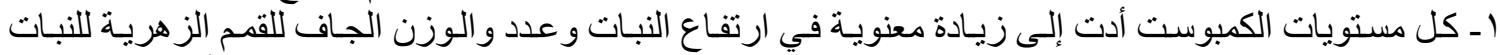

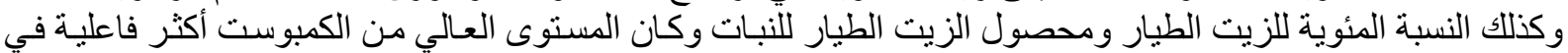




\section{M.A.H. Abdou et al.}

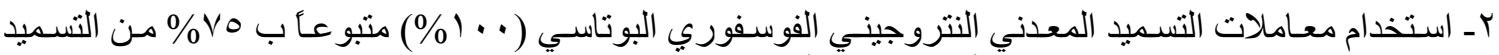

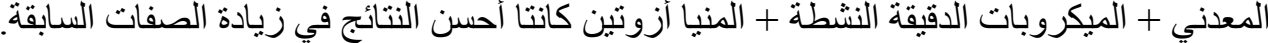

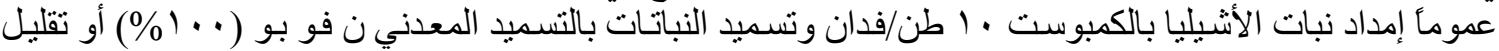

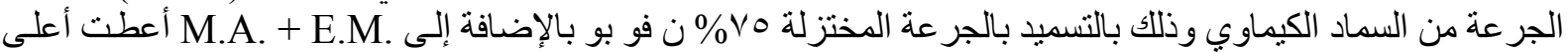
قيم لجميع الصفات المدروسة وذللك للحصول على نتائج أفضل. 